\title{
Maksimalisasi Penggunaan Metode Profile Matching dalam Menentukan Kandidat Terbaik
}

\author{
Zainal Abidin $^{1}$, Indra Gita Anugrah ${ }^{2}$, Ryco Puji Setyono ${ }^{3}$ \\ ${ }^{1,2}$ Teknik Informatika, Universitas Muhammadiyah Gresik, Gresik, Indonesia. \\ E-mail: ${ }^{1}$ zayabid.abidin@gmail.com, ${ }^{2}$ indragitaanugrah@umg.ac.id. \\ ${ }^{3}$ Management Informatika, Institut Teknologi Sepuluh Nopember, Surabaya, Indonesia. \\ E-mail: ${ }^{3}$ ryco.puji@gmail.com. \\ Submitted Date: September $18^{\text {th }}, 2019$ \\ Revised Date: October 1 ${ }^{\text {st }}, 2019$ \\ Reviewed Date: September $30^{\text {th }}, 2019$ \\ Accepted Date: October $4^{\text {th }}, 2019$
}

\begin{abstract}
Determine the best candidate in a company is something that is natural. There are several methods to determine the best candidate. One of them using the "Profile Matching" method. The method will rate employees from the highest to the lowest value, the assessment is carried out with several aspects of assessment which are categorized into two categories, namely core factors and scondary factors. Core factor is an assessment of the main factors in an assessment and the scondary factor is the supporting factors in an assessment. In weight determining the core factor and scondary factors greatly influence the results of the assessment. With the use of the "Profile Matching" method, it is expected that employee assessment can be maximized and provide results as expected. But in the calculation, there are several factors that are very influential so that the results obtained are unsuitable. Normal calculation using the Profile Matching method with standard values is the middle value produces the best candidate that is not appropriate. Requires modification of the weighting gap table so that the results produced can be maximized and appropriate.
\end{abstract}

Keywords: The Best Candidate, Decision Support System, Profile Matching

\begin{abstract}
Abstrak
Menentukan kandidat terbaik dalam suatu perusahaan adalah sesuatu yang wajar. Ada beberapa metode untuk menentukan kandidat terbaik. Salah satunya menggunakan metode "Profile Matching". Metode ini akan menilai karyawan dari nilai tertinggi ke terendah, penilaian dilakukan dengan beberapa aspek penilaian yang dikategorikan ke dalam dua kategori, yaitu core factor dan secondary factor. Core factor adalah penilaian terhadap faktor utama dalam penilaian dan secondary factor adalah faktor pendukung dalam penilaian. Dalam menentukan bobot faktor utama dan faktor pendukung sangat mempengaruhi hasil penilaian. Dengan menggunakan metode "Profile Matching", diharapkan penilaian karyawan dapat dimaksimalkan dan memberikan hasil seperti yang diharapkan. Namun dalam perhitungan ada beberapa faktor yang sangat berpengaruh sehingga hasil yang diperoleh tidak sesuai. Perhitungan normal menggunakan metode profile matching dengan nilai standar adalah nilai tengah menghasilkan kandidat terbaik yang tidak tepat. Membutuhkan modifikasi dari tabel bobot pembobotan agar hasil yang dihasilkan dapat dimaksimalkan dan sesuai.
\end{abstract}

Kata kunci: Kandidat Terbaik, Sistem Pendukung Keputusan, Profile Matching

\section{Pendahuluan}

Kandidat berdasarkan Kamus Besar Bahasa Indonesia (KBBI) adalah calon atau bakal (Kementerian Pendidikan dan Kebudayaan Republik Indonesia, 2016). Menentukan kanidat terbaik merupakan proses menentukan calon atau bakal yang memiliki kamampuan terbaik dengan beberapa aspek penilaian dan dari keseluruhan calon atau bakal yang ada.

Penentuan Kandidat terbaik dapat dilakukan dengan bantuan system pendukung keputusan. Dalam mengambil keputusan pada suatu 
perusahaan, terdapat system informasi berbasis computer yang disebut dengan Sistem Pendukung Keputusan (SPK) (Giansister, 2017).

Fokus penelitian ini untuk menganalisa penerapan perhitungan menggunakan metode Profile Matching yang digunakan untuk menentukan kandidat terbaik. Penelitian dilakuakan di PT Sinergi Informatika unit kerja di wilayah Gresik. Metode profile matching diujikan pada 9 orang kandidat dari unit kerja di wilayah Gresik.

Profile Matching adalah salah satu metode pendukung keputusan, metode tersebut digunakan untuk memberikan informasi terkait penilaian kandidat dengan meranking kandidat dan memberikan keluaran berupa nilai dengan bobot yang sudah ditentukan sebelumnya, dalam memberikan penilaian terdapat beberapa kriteria penilaian yang akan di kelompokkan menjadi secondary factor (faktor pendukung) dan core factor (faktor utama).

Penggunakan metode Profile Matching pada kasus pemilihan kandidat terbaik diharapkan dapat memberikan sebuah keputusan yang maksimal dalam menentukan kandidat terbaik diantara kandidat yang lain.

\section{Penelitian Terkait}

Penelitian oleh Umam pada tahun 2016, dalam memilih pemilihan karyawan menggunakan metode profil matching, disimpulkan bahwa metode tersebut kurang tepat karena metode tersebut menggunakan nilai standart yang dapat mempengaruhi hasil akhir, sehingga tidak sesuai dengan penilaian sebenarnya. Ketidak sesuaian tersebut dapat diantisipasi dengan menjadikan nilai tertinggi sebagai nilai standart atau nilai ideal (Umam, Arifianto, \& Cahyanto, 2016).

Sedangkan penelitian yang dilakuakan oleh Budi Sudrajat pada tahun 2018 menyimpulan bahwa proses penilaian mengunakan metode Profile Matching mampu menyeleksi dengan beberapa aspek yang ditentukan, yang mana aspek tersebut terdiri dari beberapa sub aspek. Dari hasil analisa dapat membantu pihak perusahaan dalam menentukan pegawai berprestasi (Sudrajat, 2018).

Hasil penelitian yang dilakukan oleh Heru Purwanto disimpulkan, dalam kegiatan organisasi dan manajemen sumber daya manusia metode Profile Matching direkomendasikan sebagai alternative yang dapat memudahkan dalam pengambilan keputusan. (Purwanto, 2017). Susilo pada penelitiannya memberikan kesimpulan bahwa SPK yang dibuat dapat membantu pimpinan untuk menentukan calon Ketua Program Studi. (Susilo, 2017).

Penelitian yang dilakukan oleh Astriratma menyimpulan bahwa SPK dapat menghasilkan urutan rekomendasi kandidat terbaik dalam pemilihan jabatan struktural di lingkungan Pemerintahan Kota Tarakan. Penggunaan metode profile matching untuk kasus yang mengganggap bahwa nilai tertinggi adalah nilai terbaik mengharuskan nilai ideal yang digunakan adalah nilai maksimum agar tidak terjadi ekspektasi yang melebihi nilai ideal serta perubahan bobot kriteria mempengaruhi alternatif keputusan yang dihasilkan. (Astriratma, Wardoyo, \& Musdholifah, 2017).

Haryani menyimpulkan dari penelitian yang dilakukan, bahwa Metode Profile Matching merupakan alternative untuk menentuan karyawan terbaik pada Collection Personal Loan PT. Panin Bank. Sehingga dapat dinyatakan bahwa metode tesebut dapat membantu dalam menentukan suatu keputusan dengan dipengaruhi oleh standar nilai dari setiap kriteria dalam proses menentuan karyawan terbaik (Haryani \& Fitriani, 2019).

Dari beberapa penelitian sebelumnya dapat ditarik garis besar bahwa penggunaan metode Profile Matching banyak digunakan dalam menentukan kandidat terbaik. Tetapi dalam penerapan metode tersebut terkadang hasil yang didapatkan kurang maksimal. Sehingga penelitian ini menganalisa metode Profile Matching apakah dapat memberikan hasil yang optimal jika digunakan dalam kasus menentukan kandidat terbaik.

\section{Metode Penelitian}

Metode yang dianalisa adalah metode Profile Matching. Proses perhitungan metode dimulai dari menentukan kriteria dan sub kriteria yang dinilai. Selanjutnya menentukan secondary factor (faktor pendukung) dan core factor (faktor utama) dari sub kriteria yang sudah ditentukan. Setelah ditentukan selanjutnya adalah melakukan penilaian kandidat, setelah dilakukan penilaian, langkah selanjutnya adalah memetakan gap dari masing-masing kandidat, dari gap tersebut dilakukan perhitungan pembobotan. Setelah dilakukan pembobotan, tahap selanjutnya adalah perhitungan dan pengelompokkan Nilai Secondary Factor (NSF) dan Nilai Core Factor (NCF). Dari pengelompokan tersebut dihitung nilai total penilaian. Dan tahap terakhir adalah merangking nilai total. Berikut diagram flow dari proses perhitungan metode Profile Matching. 


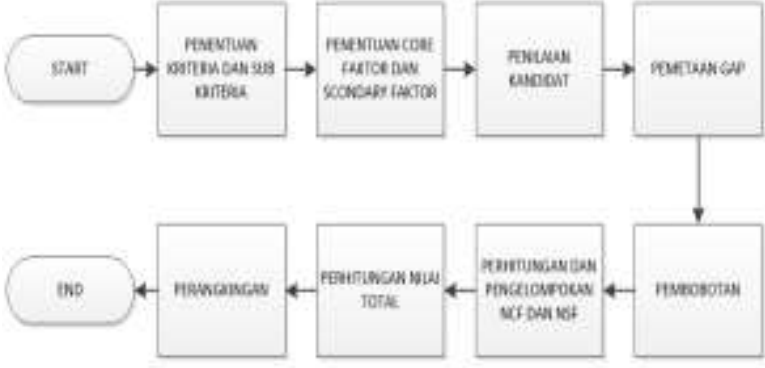

Gambar 1 Diagram Flow Profile Matching

\subsection{Penentuan Kriteria dan Sub Kriteria}

Tahap awal dalam penggunaan metode Profile Matching adalah menentukan kriteria dalam penilaian dan sub kriterianya. Pada penelitian kali ini menggunakan 3 kriteria yaitu attitude (X), skill (Y), dan loyalitas (Z). Dari ketiga kriteria tersebut ada beberapa sub kriteria yang digunakan seperti dalam bentuk tabel sebagai berikut:

Table 1 Kriteria dan Sub Kriteria

\begin{tabular}{|c|c|}
\hline KRITERIA & SUB KRITERIA \\
\hline \multirow{5}{*}{ ATTITUDE ( X) } & ( X1 ) ABSENSI KEHADIRAN \\
\hline & ( X2 ) SIKAP MENGHADAPI USER \\
\hline & ( X3 ) SIKAP MENGHADAPI ATASAN \\
\hline & ( X4 ) SIKAP DENGAN TIM / UNIT KERJA \\
\hline & ( X5 ) SIKAP INGIN BELAJAR DAN BERKEMBANG \\
\hline \multirow{6}{*}{ SKILL ( $Y)$} & ( Y1 ) KEMAMPUAN, KECEPATAN DAN KETEPATAN DALAM MENGANALISA MASALAH \\
\hline & ( Y2 ) KEMAMPUAN, KECEPATAN DAN KETEPATAN DALAM MENYELESAIKAN MASALAH \\
\hline & ( Y3 ) KEMAMPUAN, KECEPATAN DAN KETEPATAN DALAM MENGAMBIL TINDAKAN \\
\hline & (Y4 ) KAMAMPUAN BERKOMUNIKASI DENGAN USER \\
\hline & ( Y5 ) KEMAMPUAN BERKOMUNIKASI DENGAN ATASAN \\
\hline & ( Y6 ) KEMAMPUAN BERKOMUNIKASI DENGAN REKAN KERJA \\
\hline \multirow{3}{*}{ LOYALITAS ( Z ) } & ( Z1 ) KETERSEDIAAN KETIKA TERJADI PERMASALAHAN DILUAR JAM KERJA \\
\hline & ( Z2 ) KETERSEDIAAN KETIKA DITUGASKAN KELUAR KOTA \\
\hline & ( Z3 ) KETERSEDIAAN KETIKA DIBUTUHKAN ROTASI DAN MUTASI \\
\hline
\end{tabular}

\subsection{Penentuan secondary factor dan core factor}

Penentuan faktor pendukung (secondary factor) dan faktor utama (core factor) metupakan tahap kedua setelah menentukan kriteria dan sub kriteria. Sub kriteria yang sudah ditentukan diklasifikasikan menjadi dua yaitu faktor utama atau faktor pendukung, berikut tabel klasifikasi yang digunakan.

Table 2 core factor dan secondary factor

\begin{tabular}{|c|c|c|}
\hline KRITERIA & SUB KRITERIA & JENIS FAKTOR \\
\hline \multirow[t]{5}{*}{ ATTITUDE (X) } & (X1) ABSENSI KEHADIRAN & FAKTOR PENDUKUNG \\
\hline & ( X2 ) SIKAP MENGHADAPI USER & FAKTOR UTAMA \\
\hline & ( X3 ) SIKAP MENGHADAPI ATASAN & FAKTOR UTAMA \\
\hline & ( X4 ) SIKAP DENGAN TIM / UNIT KERJA & FAKTOR UTAMA \\
\hline & ( X5 ) SIKAP INGIN BELAJAR DAN BERKEMBANG & FAKTOR PENDUKUNG \\
\hline \multirow{6}{*}{ SKILL ( $Y)$} & $\begin{array}{l}\text { ( Y1 ) KEMAMPUAN, KECEPATAN DAN KETEPATAN DALAM MENGANALISA } \\
\text { MASALAH }\end{array}$ & FAKTOR UTAMA \\
\hline & $\begin{array}{l}\text { ( Y2 ) KEMAMPUAN, KECEPATAN DAN KETEPATAN DALAM MENYELESAIKAN } \\
\text { MASALAH }\end{array}$ & FAKTOR UTAMA \\
\hline & $\begin{array}{l}\text { ( Y3 ) KEMAMPUAN, KECEPATAN DAN KETEPATAN DALAM MENGAMBIL } \\
\text { TINDAKAN }\end{array}$ & FAKTOR UTAMA \\
\hline & ( Y4 ) KAMAMPUAN BERKOMUNIKASI DENGAN USER & FAKTOR PENDUKUNG \\
\hline & ( Y5 ) KEMAMPUAN BERKOMUNIKASI DENGAN ATASAN & FAKTOR PENDUKUNG \\
\hline & ( Y6 ) KEMAMPUAN BERKOMUNIKASI DENGAN REKAN KERJA & FAKTOR PENDUKUNG \\
\hline \multirow[t]{3}{*}{ LOYALITAS ( Z ) } & ( Z1 ) KETERSEDIAAN KETIKA TERJADI PERMASALAHAN DILUAR JAM KERJA & FAKTOR UTAMA \\
\hline & ( Z2 ) KETERSEDIAAN KETIKA DITUGASKAN KELUAR KOTA & FAKTOR UTAMA \\
\hline & ( Z3 ) KETERSEDIAAN KETIKA DIBUTUHKAN ROTASI DAN MUTASI & FAKTOR PENDUKUNG \\
\hline
\end{tabular}

\subsection{Penilaian Kandidat}

Tahapan selanjutnya adalah memberikan penilaian terhadap kandidat. Kandidat yang dinilai merupakan karyawan PT Sinergi Informatika unit kerja Manage Service RO Gresik sejumlah 9 orang. Berikut daftar kandidat yang dinilai. 
Table 3 Kandidat Karyawan

\begin{tabular}{|c|l|c|}
\hline NO & \multicolumn{1}{|c|}{ NAMA } & NO.BADGE \\
\hline 1 & HEMA AYUDHA & 140036 \\
\hline 2 & MOH. MARZUQI F & 140041 \\
\hline 3 & OKKE BOMARAHANTA & 150094 \\
\hline 4 & M.ADINURA ARRIZKY & 150096 \\
\hline 5 & DHAMAR SEPTIAN & 170061 \\
\hline 6 & BAYU SATRIA KUSUMA & 170069 \\
\hline 7 & IMAM WAHYUDI & 170084 \\
\hline 8 & RIDLO BIAGGI & 170095 \\
\hline 9 & NURHADI KUSDIANTO & 170126 \\
\hline
\end{tabular}

Penilaian kandidat diberikan oleh atasan langsung maupun customer yang bersinggungan langsung dengan teknisi. Sehingga nilai yang didapatnya lebih real sesuai dengan keadaan yang sesungguhnya. Penilaian di berikan berdasarkan tabel sebagai berikut:

Table 4 Penilaian

\begin{tabular}{|c|l|}
\hline NILAI & \multicolumn{1}{|c|}{ KETERANGAN } \\
\hline E & TIDAK BAIK \\
\hline D & KURANG BAIK \\
\hline C & CUKUP BAIK \\
\hline B & BAIK \\
\hline A & SANGAT BAIK \\
\hline
\end{tabular}

\subsection{Pemetakan gap}

Gap merupakan jarak anatara nilai yang didapat oleh kandidat dengan nilai standart yang ditentukan. Sebelum menghitung gap, nilai kandidat dikonversi menjadi skor terlebih dahulu. Adapun konversinya sebagi berikut:
Table 5 Konversi Skor

\begin{tabular}{|c|c|l|}
\hline SKOR & NILAI & \multicolumn{1}{|c|}{ KETERANGAN } \\
\hline 1 & E & TIDAK BAIK \\
\hline 2 & D & KURANG BAIK \\
\hline 3 & C & CUKUP BAIK \\
\hline 4 & B & BAIK \\
\hline 5 & A & SANGAT BAIK \\
\hline
\end{tabular}

Setelah nilai dikonversi maka selanjutnya menentukan nilai standart yang diinginkan. Pada penelitian kali ini menggunakan nilai standart B (Baik) dengan Skor 4.

Table 6 Profile Standart

\begin{tabular}{|c|c|l|}
\hline SKOR & NILAI & KETERANGAN \\
\hline 1 & E & TIDAK BAIK \\
\hline 2 & D & KURANG BAIK \\
\hline 3 & C & CUKUP BAIK \\
\hline 4 & B & BAIK \\
\hline 5 & A & SANGAT BAIK \\
\hline
\end{tabular}

Setelah nilai dikonversi dan telah ditentukan standart yang digunakan, tahap selanjutnya menghitung gap dari masing-masing kandidat dari setiap sub kriteria penilaian. Gap didapatkan dari rumus perhitungan berikut:

\section{GAP = Nilai Pegawai - Nilai Standart}

\subsection{Pembobotan}

Tahap pembobotan merupakan tahap konversi dari nilai gap ke nilai bobot. Berikut tabel konversi yang digunakan untuk mengubah nilai gap ke nilai bobot pada tabel 7 .

Table 7 Konversi Bobot gap

\begin{tabular}{|c|l|c|}
\hline $\begin{array}{c}\text { Nilai } \\
\text { gap }\end{array}$ & \multicolumn{1}{|c|}{ KETERANGAN } & $\begin{array}{c}\text { BOBOT } \\
\text { NILAI }\end{array}$ \\
\hline 0 & TIDAK ADA SELISIH ANTARA NILAI SKOR INDIVIDU DENGAN NILAI PROFIL STANDART & 5 \\
\hline 1 & NILAI SKOR INDIVIDU LEBIH TINGGI 1 POINT DARI NILAI PROFIL STANDART & 4.5 \\
\hline-1 & NILAI SKOR INDIVIDU LEBIH RENDAH 1 POINT DARI NILAI PROFIL STANDART & 4 \\
\hline 2 & NILAI SKOR INDIVIDU LEBIH TINGGI 2 POINT DARI NILAI PROFIL STANDART & 3.5 \\
\hline-2 & NILAI SKOR INDIVIDU LEBIH RENDAH 2 POINT DARI NILAI PROFIL STANDART & 3 \\
\hline 3 & NILAI SKOR INDIVIDU LEBIH TINGGI 3 POINT DARI NILAI PROFIL STANDART & 2.5 \\
\hline-3 & NILAI SKOR INDIVIDU LEBIH RENDAH 3 POINT DARI NILAI PROFIL STANDART & 2 \\
\hline 4 & NILAI SKOR INDIVIDU LEBIH TINGGI 4 POINT DARI NILAI PROFIL STANDART & 1.5 \\
\hline-4 & NILAI SKOR INDIVIDU LEBIH RENDAH 4 POINT DARI NILAI PROFIL STANDART & 1 \\
\hline
\end{tabular}

Dari melihat tabel 7 menggambarkan bahwasanya ketika nilai kandidat mendekati nilai standart yang ditentukan maka nilai bobotnya semakin besar, begitu juga sebaliknya jika nilai kandidat semakin jauh dari nilai standart maka nilai bobot semakin kecil.

\subsection{Perhitungan (NCF, NSF dan Nilai Kriteria), Pengelompokan (NCF, NSF dan Nilai Kriteria)}

Proses perhitungan ini merupakan proses di mana menghitung rata-rata nilai faktor pendukung (secondary factor) dan nilai utama (core factor) yang diambil dari nilai bobot tahap sebelumnya. Nilai NSF dan NCF dihitung pada setiap kriteria. 
Nilai kriteria didapatkan dari nilai NSF dan NCF yang dikalikan dengan perbandingan bobot secondary factor dan core factor. Perbandingan bobot yang digunakan adalah 30\% untuk faktor pendukung (secondary factor) dan $70 \%$ untuk faktor utama (core factor) dan Berikut perhitungan rumus yang digunakan.

Perhitunagn NCF, NSF dan Nilai Kriteria X

$$
\mathrm{NCF}(X)=\frac{\sum \mathrm{NC}(X)}{\sum \mathrm{IC}(X)}
$$

Keterangan:

$\mathrm{NCF}(\mathrm{X})$ : Nilai rata - rata faktor utama (Core Factor) kriteria X

$\mathrm{NC}(\mathrm{X}) \quad$ : Jumlah total nilai faktor utama (Core Factor) kriteria X

$\mathrm{IC}(\mathrm{X}) \quad$ : Jumlah sub kategori faktor utama (Core Factor) Kriteria X

$$
\operatorname{NSF}(X)=\frac{\sum N S(X)}{\sum I S(X)}
$$

Keterangan:

$\mathrm{NSF}(\mathrm{X})$ : Nilai rata -rata faktor pendukung (Secondary Factor) Kriteria X

NS(X) : Jumlah total nilai faktor pendukung (Secondary Factor) Kriteria X

IS(X) : Jumlah sub kategori faktor pendukung (Secondary Factor) Kriteria X

Setelah menghitung nilai NSF dan NCF pada kriteria $\mathrm{X}$ langkah selanjutnya adalah menghitung nilai $X$. Nilai $X$ dapat dicari menggunakan rumus berikut:

$$
\text { Nilai } X=70 \% * \mathrm{NCF}(X)+30 \% * \mathrm{NSF}(X)
$$

Keterangan:

$\begin{array}{ll}\text { Nilai X } & \text { : Nilai kriteria X } \\ 70 \% & \text { : Bobot faktor utama (Core } \\ & \text { Factor) } \\ 30 \% & \text { : Bobot faktor pendukung } \\ & \text { (Secondary Factor) } \\ \mathrm{NCF}(\mathrm{X}) & \begin{array}{l}\text { : Nilai rata - rata faktor utama } \\ \text { (Core Factor) kriteria X }\end{array} \\ \mathrm{NSF}(\mathrm{X}) & \begin{array}{l}\text { : Nilai rata - rata faktor } \\ \text { pendukung (Secondary Factor) } \\ \text { kriteria X }\end{array}\end{array}$

\section{$>$ Perhitunagn NCF, NSF dan Nilai Kriteria Y dan $Z$}

Perhitungan NCF, NSF beserta nilai $\mathrm{Y}$ dan Nilai Z. Menggunakan rumus perhitungan seperti perhitungan nilai NCF, NSF dan nilai $X$. yang membedakan hanya kriterianya saja.

Dari perhitungan NCF dan NSF menghasilkan nilai kriteria $\mathrm{X}, \mathrm{Y}$ dan $\mathrm{Z}$ dari masingmasing kandidat yang digunakan untuk mencari nilai akhir.

\subsection{Perhitungan Nilai Akhir}

Sebelem dilakukan perhitungan nilai akhir, terlebih dahulu ditentukan prosentase dari setiap kriteria yang digunakan. Berikut prosentase yang digunakan dalam penelitian.

$$
\begin{array}{ll}
\text { Attitude }(\mathrm{X}) & =30 \% \\
\text { Skill }(\mathrm{Y}) & =40 \% \\
\text { Loyalitas }(\mathrm{Z}) & =30 \%
\end{array}
$$

Setelah ditentukan prosentase maka langkah selanjutnya menghitung nilai akhir. Nilai akhir dapat di hitung sengan rumus perhitungan sebagai berikut:

$$
\begin{aligned}
& \text { Nilai Akhir }=30 \% * X+40 \% * Y+30 \% * Z \\
& \text { Keterangan: } \\
& \text { Nilai akhir : Nilai akhir yang didapatkan } \\
& 30 \% \quad \text { : Bobot kriteria X (Attitude) } \\
& \mathrm{X} \quad \text { : Nilai X } \\
& 40 \% \quad: \text { Bobot kriteria Y (Skill) } \\
& \mathrm{Y} \quad \text { : Nilai Y } \\
& \text { 30\% : Bobot kriteria Z (Loyalitas) } \\
& \text { Z : Nilai Z }
\end{aligned}
$$

\subsection{Pemeringkatan}

Pemeringkatan adalah tahap di mana proses pengurutan kandidat yang diurutkan berdasarkan nilai akhir tertinggi ke nilai terendah. Dari pemeringkatan ini dapat diketahui kandidat mana yang berhak untuk dilakukan proses promosi lebih lanjut.

\section{Hasil dan Pembahasan}

Pada poin ini membahas mengenai implementasi dan analisa perhitungan metode Profile Matching dengan membandingkan hasil antara perhitungan secara normal dengan perhitungan modifikasi. 


\subsection{Perhitungan Normal Metode Profile Matching}

Pada pembahasan metode telah ditentukan kriteria, sub kriteria, klasifikasi faktor utama (core factor) dan faktor pendukung (secondary faktor). Tahap selanjutnya adalah penilaian kandidat. Berikut penilaian kandidat yang diperoleh pada tabel 8. Dari penilaian kandidat, dikonversi menjadi skor kandidat yang bisa ditampilkan pada tabel 9. Dari skor kandidat tahap selanjutnya adalah perhitungan gap antara skor kandidat dengan profile standart / nilai standart. Hasil perhitungan gap dapat ditampilkan pada tabel 10. Dari nilai gap pada tabel 10 dikonversi menjadi bobot gap. Perhitungan pembobotan sesuai dengan Tabel 7 Konversi Bobot gap. Hasil konversi bobot gap dapat ditampilkan pada tabel 11.

Table 8 Penilaian Kandidat

\begin{tabular}{|c|c|c|c|c|c|c|c|c|c|c|c|c|c|c|c|c|}
\hline \multirow{2}{*}{ NO } & \multirow{2}{*}{ NAMA } & \multirow{2}{*}{ NO.BADGE } & \multicolumn{5}{|c|}{ ATTITUDE ( X ) } & \multicolumn{6}{|c|}{ SKILL ( Y ) } & \multicolumn{3}{|c|}{ LOYALITAS ( Z ) } \\
\hline & & & $\mathrm{X} 1$ & $\mathrm{X} 2$ & $\mathrm{x} 3$ & $\mathrm{X} 4$ & $\mathrm{X} 5$ & Y1 & Y2 & Y3 & Y4 & Y5 & Y6 & $\mathrm{Z1}$ & $\mathrm{Z2}$ & $\mathrm{Z3}$ \\
\hline 1 & HEMA AYUDHA & 140036 & $B$ & $C$ & $B$ & $C$ & $C$ & $C$ & $C$ & $B$ & $B$ & $C$ & $B$ & $B$ & $\mathrm{C}$ & C \\
\hline 2 & MOH. MARZUQI F & 140041 & $\mathrm{~B}$ & $\mathrm{~B}$ & $\mathrm{~B}$ & $\mathrm{~B}$ & $\mathrm{~B}$ & $\mathrm{~B}$ & $\mathrm{~B}$ & $\mathrm{~B}$ & A & $\mathrm{B}$ & $\mathrm{B}$ & C & $\mathrm{B}$ & $\mathrm{C}$ \\
\hline 3 & OKKE BOMARAHANTA & 150094 & $\mathrm{D}$ & $\mathrm{C}$ & B & $\mathrm{C}$ & C & $\mathrm{C}$ & $B$ & B & A & $\mathrm{C}$ & C & $\mathrm{D}$ & A & $\mathrm{B}$ \\
\hline 4 & M.ADINURA ARRIZKY & 150096 & C & C & C & C & D & C & B & B & A & C & $\mathrm{B}$ & $\mathrm{D}$ & $\mathrm{D}$ & $\mathrm{C}$ \\
\hline 5 & DHAMAR SEPTIAN & 170061 & B & B & B & B & B & A & B & B & $B$ & B & A & A & B & C \\
\hline 6 & BAYU SATRIA KUSUMA & 170069 & B & $\mathrm{B}$ & B & $\mathrm{B}$ & $\mathrm{A}$ & $\mathrm{A}$ & A & $\mathrm{B}$ & $\mathrm{B}$ & $\mathrm{B}$ & A & A & $\mathrm{A}$ & $\mathrm{B}$ \\
\hline 7 & IMAM WAHYUDI & 170084 & $\mathrm{~B}$ & B & B & B & B & C & $\mathrm{B}$ & $\mathrm{B}$ & B & $\mathrm{B}$ & $\mathrm{B}$ & A & $\mathrm{B}$ & $\mathrm{C}$ \\
\hline 8 & RIDLO BIAGGI & 170095 & B & $B$ & $\mathrm{~B}$ & B & $\mathrm{A}$ & $\mathrm{A}$ & $B$ & $\mathrm{~B}$ & $\mathrm{~B}$ & $\mathrm{~B}$ & $\mathrm{~A}$ & A & $\mathrm{C}$ & $\mathrm{B}$ \\
\hline 9 & NURHADI KUSDIANTO & 170126 & $\mathrm{~B}$ & $\mathrm{~B}$ & $\mathrm{~B}$ & $\mathrm{~B}$ & $\mathrm{~B}$ & $\mathrm{~B}$ & $\mathrm{~B}$ & $\mathrm{~B}$ & $\mathrm{~B}$ & $\mathrm{~B}$ & A & A & $\mathrm{A}$ & $\mathrm{B}$ \\
\hline
\end{tabular}

Table 9 Skor Kandidat

\begin{tabular}{|c|c|c|c|c|c|c|c|c|c|c|c|c|c|c|c|c|}
\hline \multirow{2}{*}{ NO } & \multirow{2}{*}{ NAMA } & \multirow{2}{*}{ NO.BADGE } & \multicolumn{5}{|c|}{ ATTITUDE (X) } & \multicolumn{6}{|c|}{ SKILL ( Y ) } & \multicolumn{3}{|c|}{ LOYALITAS ( Z ) } \\
\hline & & & $\mathrm{X} 1$ & $\mathrm{X} 2$ & X3 & $\mathrm{X} 4$ & $\mathrm{x} 5$ & Y1 & Y2 & Y3 & Y4 & Y5 & Y6 & $\mathrm{Z1}$ & $\mathrm{Z2}$ & $\mathrm{Z3}$ \\
\hline 1 & HEMA AYUDHA & 140036 & 4 & 3 & 4 & 3 & 3 & 3 & 3 & 4 & 4 & 3 & 4 & 4 & 3 & 3 \\
\hline 2 & MOH. MARZUQI F & 140041 & 4 & 4 & 4 & 4 & 4 & 4 & 4 & 4 & 5 & 4 & 4 & 3 & 4 & 3 \\
\hline 3 & OKKE BOMARAHANTA & 150094 & 2 & 3 & 4 & 3 & 3 & 3 & 4 & 4 & 5 & 3 & 3 & 2 & 5 & 4 \\
\hline 4 & M.ADINURA ARRIZKY & 150096 & 3 & 3 & 3 & 3 & 2 & 3 & 4 & 4 & 5 & 3 & 4 & 2 & 2 & 3 \\
\hline 5 & DHAMAR SEPTIAN & 170061 & 4 & 4 & 4 & 4 & 4 & 5 & 4 & 4 & 4 & 4 & 5 & 5 & 4 & 3 \\
\hline 6 & BAYU SATRIA KUSUMA & 170069 & 4 & 4 & 4 & 4 & 5 & 5 & 5 & 4 & 4 & 4 & 5 & 5 & 5 & 4 \\
\hline 7 & IMAM WAHYUDI & 170084 & 4 & 4 & 4 & 4 & 4 & 3 & 4 & 4 & 4 & 4 & 4 & 5 & 4 & 3 \\
\hline 8 & RIDLO BIAGGI & 170095 & 4 & 4 & 4 & 4 & 5 & 5 & 4 & 4 & 4 & 4 & 5 & 5 & 3 & 4 \\
\hline 9 & NURHADI KUSDIANTO & 170126 & 4 & 4 & 4 & 4 & 4 & 4 & 4 & 4 & 4 & 4 & 5 & 5 & 5 & 4 \\
\hline
\end{tabular}

Table 10 Perhitungan gap Kandidat

\begin{tabular}{|c|c|c|c|c|c|c|c|c|c|c|c|c|c|c|c|c|}
\hline \multirow{2}{*}{ NO } & \multirow{2}{*}{ NAMA } & \multirow{2}{*}{ NO.BADGE } & \multicolumn{5}{|c|}{ ATTITUDE ( X) } & \multicolumn{6}{|c|}{ SKILL (Y) } & \multicolumn{3}{|c|}{ LOYALITAS ( Z ) } \\
\hline & & & $\mathrm{X} 1$ & $\mathrm{X} 2$ & X3 & $\mathrm{X} 4$ & $\mathrm{x} 5$ & Y1 & $\mathrm{Y} 2$ & Y3 & Y4 & Y5 & Y6 & $\mathrm{Z1}$ & $\mathrm{Z2}$ & $\mathrm{Z3}$ \\
\hline 1 & HEMA AYUDHA & 140036 & 4 & 3 & 4 & 3 & 3 & 3 & 3 & 4 & 4 & 3 & 4 & 4 & 3 & 3 \\
\hline 2 & MOH. MARZUQI F & 140041 & 4 & 4 & 4 & 4 & 4 & 4 & 4 & 4 & 5 & 4 & 4 & 3 & 4 & 3 \\
\hline 3 & OKKE BOMARAHANTA & 150094 & 2 & 3 & 4 & 3 & 3 & 3 & 4 & 4 & 5 & 3 & 3 & 2 & 5 & 4 \\
\hline 4 & M.ADINURA ARRIZKY & 150096 & 3 & 3 & 3 & 3 & 2 & 3 & 4 & 4 & 5 & 3 & 4 & 2 & 2 & 3 \\
\hline 5 & DHAMAR SEPTIAN & 170061 & 4 & 4 & 4 & 4 & 4 & 5 & 4 & 4 & 4 & 4 & 5 & 5 & 4 & 3 \\
\hline 6 & BAYU SATRIA KUSUMA & 170069 & 4 & 4 & 4 & 4 & 5 & 5 & 5 & 4 & 4 & 4 & 5 & 5 & 5 & 4 \\
\hline 7 & IMAM WAHYUDI & 170084 & 4 & 4 & 4 & 4 & 4 & 3 & 4 & 4 & 4 & 4 & 4 & 5 & 4 & 3 \\
\hline 8 & RIDLO BIAGGI & 170095 & 4 & 4 & 4 & 4 & 5 & 5 & 4 & 4 & 4 & 4 & 5 & 5 & 3 & 4 \\
\hline 9 & NURHADI KUSDIANTO & 170126 & 4 & 4 & 4 & 4 & 4 & 4 & 4 & 4 & 4 & 4 & 5 & 5 & 5 & 4 \\
\hline & PROFIL STANDAR & & 4 & 4 & 4 & 4 & 4 & 4 & 4 & 4 & 4 & 4 & 4 & 4 & 4 & 4 \\
\hline 1 & HEMA AYUDHA & 140036 & 0 & -1 & 0 & -1 & -1 & -1 & -1 & 0 & 0 & -1 & 0 & 0 & -1 & -1 \\
\hline 2 & MOH. MARZUQI F & 140041 & 0 & 0 & 0 & 0 & 0 & 0 & 0 & 0 & 1 & 0 & 0 & -1 & 0 & -1 \\
\hline 3 & OKKE BOMARAHANTA & 150094 & -2 & -1 & 0 & -1 & -1 & -1 & 0 & 0 & 1 & -1 & -1 & -2 & 1 & 0 \\
\hline 4 & M.ADINURA ARRIZKY & 150096 & -1 & -1 & -1 & -1 & -2 & -1 & 0 & 0 & 1 & -1 & 0 & -2 & -2 & -1 \\
\hline 5 & DHAMAR SEPTIAN & 170061 & 0 & 0 & 0 & 0 & 0 & 1 & 0 & 0 & 0 & 0 & 1 & 1 & 0 & -1 \\
\hline 6 & BAYU SATRIA KUSUMA & 170069 & 0 & 0 & 0 & 0 & 1 & 1 & 1 & 0 & 0 & 0 & 1 & 1 & 1 & 0 \\
\hline 7 & IMAM WAHYUDI & 170084 & 0 & 0 & 0 & 0 & 0 & -1 & 0 & 0 & 0 & 0 & 0 & 1 & 0 & -1 \\
\hline 8 & RIDLO BIAGGI & 170095 & 0 & 0 & 0 & 0 & 1 & 1 & 0 & 0 & 0 & 0 & 1 & 1 & -1 & 0 \\
\hline 9 & NURHADI KUSDIANTO & 170126 & 0 & 0 & 0 & 0 & 0 & 0 & 0 & 0 & 0 & 0 & 1 & 1 & 1 & 0 \\
\hline
\end{tabular}


Table 11 Perhitungan Konversi gap

\begin{tabular}{|c|c|c|c|c|c|c|c|c|c|c|c|c|c|c|c|c|}
\hline \multirow{2}{*}{ NO } & \multirow{2}{*}{ NAMA } & \multirow{2}{*}{ NO.BADGE } & \multicolumn{5}{|c|}{ ATTITUDE (X) } & \multicolumn{6}{|c|}{ SKILL (Y) } & \multicolumn{3}{|c|}{ LOYALITAS ( Z ) } \\
\hline & & & $\mathrm{X} 1$ & $\mathrm{X} 2$ & $\mathrm{x} 3$ & $x 4$ & $\mathrm{x} 5$ & $\mathrm{Y} 1$ & Y2 & Y3 & Y4 & Y5 & Y6 & $\mathrm{Z1}$ & $\mathrm{Z2}$ & Z3 \\
\hline 1 & HEMA AYUDHA & 140036 & 5 & 4 & 5 & 4 & 4 & 4 & 4 & 5 & 5 & 4 & 5 & 5 & 4 & 4 \\
\hline 2 & MOH. MARZUQI F & 140041 & 5 & 5 & 5 & 5 & 5 & 5 & 5 & 5 & 4.5 & 5 & 5 & 4 & 5 & 4 \\
\hline 3 & OKKE BOMARAHANTA & 150094 & 3 & 4 & 5 & 4 & 4 & 4 & 5 & 5 & 4.5 & 4 & 4 & 3 & 4.5 & 5 \\
\hline 4 & M.ADINURA ARRIZKY & 150096 & 4 & 4 & 4 & 4 & 3 & 4 & 5 & 5 & 4.5 & 4 & 5 & 3 & 3 & 4 \\
\hline 5 & DHAMAR SEPTIAN & 170061 & 5 & 5 & 5 & 5 & 5 & 4.5 & 5 & 5 & 5 & 5 & 4.5 & 4.5 & 5 & 4 \\
\hline 6 & BAYU SATRIA KUSUMA & 170069 & 5 & 5 & 5 & 5 & 4.5 & 4.5 & 4.5 & 5 & 5 & 5 & 4.5 & 4.5 & 4.5 & 5 \\
\hline 7 & IMAM WAHYUDI & 170084 & 5 & 5 & 5 & 5 & 5 & 4 & 5 & 5 & 5 & 5 & 5 & 4.5 & 5 & 4 \\
\hline 8 & RIDLO BIAGGI & 170095 & 5 & 5 & 5 & 5 & 4.5 & 4.5 & 5 & 5 & 5 & 5 & 4.5 & 4.5 & 4 & 5 \\
\hline 9 & NURHADI KUSDIANTO & 170126 & 5 & 5 & 5 & 5 & 5 & 5 & 5 & 5 & 5 & 5 & 4.5 & 4.5 & 4.5 & 5 \\
\hline
\end{tabular}

Dari nilai konversi gap selanjutnya dilakukan perhitungan NSF dan NCF serta nilai Kriteria. Berikut hasil perhitungan NSF dan NCF.

Table 12 Perhitungan NCF dan NSF kriteria X

\begin{tabular}{|c|c|c|c|c|c|c|c|c|c|c|}
\hline \multirow{2}{*}{ NO } & \multirow{2}{*}{ NAMA } & \multirow{2}{*}{ NO.BADGE } & \multicolumn{5}{|c|}{ ATTITUDE (X) } & \multirow{2}{*}{$\begin{array}{l}\text { NILAI FAKTOR } \\
\text { UTAMA }\end{array}$} & \multirow{2}{*}{$\begin{array}{l}\text { NILAI FAKTOR } \\
\text { PENDUKUNG }\end{array}$} & \multirow{2}{*}{$\begin{array}{l}\text { NILAI } \\
X\end{array}$} \\
\hline & & & $\mathrm{X} 1$ & $\mathrm{X} 2$ & $\mathrm{X3}$ & $\mathrm{X} 4$ & $\mathrm{X} 5$ & & & \\
\hline 1 & HEMA AYUDHA & 140036 & 5 & 4 & 5 & 4 & 4 & 4.33 & 4.50 & 4.38 \\
\hline 2 & MOH. MARZUQI F & 140041 & 5 & 5 & 5 & 5 & 5 & 5.00 & 5.00 & 5.00 \\
\hline 3 & OKKE BOMARAHANTA & 150094 & 3 & 4 & 5 & 4 & 4 & 4.33 & 3.50 & 4.08 \\
\hline 4 & M.ADINURA ARRIZKY & 150096 & 4 & 4 & 4 & 4 & 3 & 4.00 & 3.50 & 3.85 \\
\hline 5 & DHAMAR SEPTIAN & 170061 & 5 & 5 & 5 & 5 & 5 & 5.00 & 5.00 & 5.00 \\
\hline 6 & BAYU SATRIA KUSUMA & 170069 & 5 & 5 & 5 & 5 & 4.5 & 5.00 & 4.75 & 4.93 \\
\hline 7 & IMAM WAHYUDI & 170084 & 5 & 5 & 5 & 5 & 5 & 5.00 & 5.00 & 5.00 \\
\hline 8 & RIDLO BIAGGI & 170095 & 5 & 5 & 5 & 5 & 4.5 & 5.00 & 4.75 & 4.93 \\
\hline 9 & NURHADI KUSDIANTO & 170126 & 5 & 5 & 5 & 5 & 5 & 5.00 & 5.00 & 5.00 \\
\hline
\end{tabular}

Keterangan:

Cell biru

Cell Kuning

: Core Factor

: Secondary Factor

NCF X $($ Hema $)=\underline{X 2+X 3+X 4}$

$$
3
$$$$
=\underline{4+5+4}
$$

$=4.33$

$$
\begin{aligned}
\operatorname{NSF} X(\text { Hema }) & =\frac{X 1+X 5}{2} \\
& =\frac{5+4}{2} \\
& =4.50
\end{aligned}
$$

Nilai X (Hema)

$=70 \% * \mathrm{NCF}(\mathrm{X})+\mathbf{3 0} \% * \mathbf{N S F}(\mathrm{X})$

\begin{tabular}{|c|c|c|c|c|c|c|c|c|c|c|c|}
\hline \multirow{2}{*}{ NO } & \multirow{2}{*}{ NAMA } & \multirow{2}{*}{ NO.BADGE } & \multicolumn{6}{|c|}{ SKILL ( Y ) } & \multirow{2}{*}{$\begin{array}{c}\text { NILAI FAKTOR } \\
\text { UTAMA }\end{array}$} & \multirow{2}{*}{$\begin{array}{l}\text { NILAI FAKTOR } \\
\text { PENDUKUNG }\end{array}$} & \multirow{2}{*}{ NILAI Y } \\
\hline & & & $\mathrm{Y} 1$ & $\mathrm{Y} 2$ & Y3 & Y4 & Y5 & Y6 & & & \\
\hline 1 & HEMA AYUDHA & 140036 & 4 & 4 & 5 & 5 & 4 & 5 & 4.33 & 4.67 & 4.43 \\
\hline 2 & MOH. MARZUQI F & 140041 & 5 & 5 & 5 & 4.5 & 5 & 5 & 5.00 & 4.83 & 4.95 \\
\hline 3 & OKKE BOMARAHANTA & 150094 & 4 & 5 & 5 & 4.5 & 4 & 4 & 4.67 & 4.17 & 4.52 \\
\hline 4 & M.ADINURA ARRIZKY & 150096 & 4 & 5 & 5 & 4.5 & 4 & 5 & 4.67 & 4.50 & 4.62 \\
\hline 5 & DHAMAR SEPTIAN & 170061 & 4.5 & 5 & 5 & 5 & 5 & 4.5 & 4.83 & 4.83 & 4.83 \\
\hline 6 & BAYU SATRIA KUSUMA & 170069 & 4.5 & 4.5 & 5 & 5 & 5 & 4.5 & 4.67 & 4.83 & 4.72 \\
\hline 7 & IMAM WAHYUDI & 170084 & 4 & 5 & 5 & 5 & 5 & 5 & 4.67 & 5.00 & 4.77 \\
\hline 8 & RIDLO BIAGGI & 170095 & 4.5 & 5 & 5 & 5 & 5 & 4.5 & 4.83 & 4.83 & 4.83 \\
\hline 9 & NURHADI KUSDIANTO & 170126 & 5 & 5 & 5 & 5 & 5 & 4.5 & 5.00 & 4.83 & 4.95 \\
\hline
\end{tabular}

$=70 \% * 4.33+30 \% * 4.50$

$=4.38$

Table 13 Perhitungan NCF dan NSF kriteria Y 


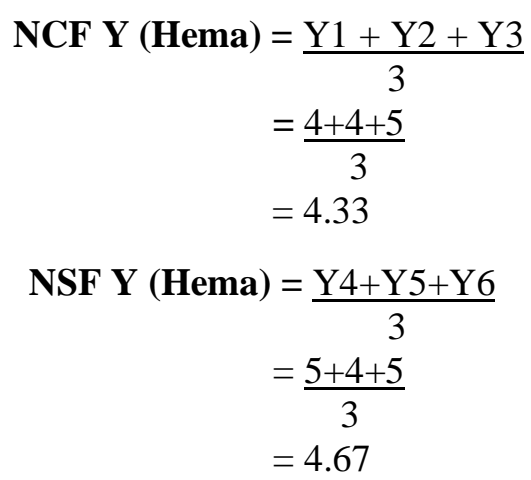

Nilai Y (Hema)

$=70 \% * \mathbf{N C F}(\mathbf{Y})+30 \% * \mathbf{N S F}(\mathbf{Y})$

$=70 \% * 4.33+30 \% * 4.67$

$=4.43$

Table 14 Perhitungan NCF dan NSF kriteria $Z$

\begin{tabular}{|c|c|c|c|c|c|c|c|c|}
\hline \multirow{2}{*}{ NO } & \multirow{2}{*}{ NAMA } & \multirow{2}{*}{ NO.BADGE } & \multicolumn{3}{|c|}{ LOYALITAS ( Z ) } & \multirow{2}{*}{$\begin{array}{l}\text { NILAI FAKTOR } \\
\text { UTAMA }\end{array}$} & \multirow{2}{*}{$\begin{array}{l}\text { NILAI FAKTOR } \\
\text { PENDUKUNG }\end{array}$} & \multirow{2}{*}{ NILAI Z } \\
\hline & & & $\mathrm{Z1}$ & $\mathrm{Z2}$ & Z3 & & & \\
\hline 1 & HEMA AYUDHA & 140036 & 5 & 4 & 4 & 4.50 & 4.00 & 4.35 \\
\hline 2 & MOH. MARZUQI F & 140041 & 4 & 5 & 4 & 4.50 & 4.00 & 4.35 \\
\hline 3 & OKKE BOMARAHANTA & 150094 & 3 & 4.5 & 5 & 3.75 & 5.00 & 4.13 \\
\hline 4 & M.ADINURA ARRIZKY & 150096 & 3 & 3 & 4 & 3.00 & 4.00 & 3.30 \\
\hline 5 & DHAMAR SEPTIAN & 170061 & 4.5 & 5 & 4 & 4.75 & 4.00 & 4.53 \\
\hline 6 & BAYU SATRIA KUSUMA & 170069 & 4.5 & 4.5 & 5 & 4.50 & 5.00 & 4.65 \\
\hline 7 & IMAM WAHYUDI & 170084 & 4.5 & 5 & 4 & 4.75 & 4.00 & 4.53 \\
\hline 8 & RIDLO BIAGGI & 170095 & 4.5 & 4 & 5 & 4.25 & 5.00 & 4.48 \\
\hline 9 & NURHADI KUSDIANTO & 170126 & 4.5 & 4.5 & 5 & 4.50 & 5.00 & 4.65 \\
\hline
\end{tabular}

$$
\begin{aligned}
\text { NCF Z (Hema) } & =\frac{Z 1+Z 2}{2} \\
& =\frac{5+4}{2} \\
& =4.50 \\
\text { NSF Z (Hema) } & =\frac{Z 3}{1} \\
& =\frac{4}{1} \\
& =4.00
\end{aligned}
$$

\section{Nilai Z (Hema)}

$=70 \% * \mathrm{NCF}(\mathrm{Z})+30 \% * \mathrm{NSF}(\mathrm{Z})$ $=70 \% * 4.50+30 \% * 4.00$

$$
=4.38
$$

Setelah didapatkan nilai kriteria $\mathrm{X}, \mathrm{Y}$ dan $\mathrm{Z}$ tahap selajutnya menghitung nilai akhir dari masing - masing kandidat. Berikut perhitungan nilai akhir kandidat pada tabel 15.

Table 15 Perhitungan Nilai Akhir

\begin{tabular}{|c|l|c|c|c|c|c|}
\hline NO & \multicolumn{1}{|c|}{ NAMA } & NO.BADGE & $\begin{array}{c}\text { NILAIX } \\
(30 \%)\end{array}$ & $\begin{array}{c}\text { NILAI Y } \\
(40 \%)\end{array}$ & $\begin{array}{c}\text { NILAI Z } \\
(30 \%)\end{array}$ & $\begin{array}{c}\text { NILAI } \\
\text { AKHIR }\end{array}$ \\
\hline 1 & HEMA AYUDHA & 140036 & 4.38 & 4.43 & 4.35 & 4.39 \\
\hline 2 & MOH. MARZUQI F & 140041 & 5.00 & 4.95 & 4.35 & 4.79 \\
\hline 3 & OKKE BOMARAHANTA & 150094 & 4.08 & 4.52 & 4.13 & 4.27 \\
\hline 4 & M.ADINURA ARRIZKY & 150096 & 3.85 & 4.62 & 3.30 & 3.99 \\
\hline 5 & DHAMAR SEPTIAN & 170061 & 5.00 & 4.83 & 4.53 & 4.79 \\
\hline 6 & BAYU SATRIA KUSUMA & 170069 & 4.93 & 4.72 & 4.65 & 4.76 \\
\hline 7 & IMAM WAHYUDI & 170084 & 5.00 & 4.77 & 4.53 & 4.76 \\
\hline 8 & RIDLO BIAGGI & 170095 & 4.93 & 4.83 & 4.48 & 4.75 \\
\hline 9 & NURHADI KUSDIANTO & 170126 & 5.00 & 4.95 & 4.65 & 4.88 \\
\hline
\end{tabular}

\section{Nilai Akhir (Hema)}

$=30 \% * \mathbf{X}+\mathbf{4 0} \% * \mathbf{Y}+\mathbf{3 0} \% * \mathbf{Z}$

$=30 \% * 4.38+40 \% * 4.43+30 \% * 4.35$

$=4.39$
Setelah didapatkan nilai akhir, tahap selanjutnya dari perhitungan metode Profile Matching adalah merangking kandidat berdasarkan nilai akhir. Berikut hasil ranking kandidat yang dapat dilihat pada tabel 16 . 


\begin{tabular}{|c|l|c|c|c|c|c|}
\hline TOable 16 Hasil Ranking \\
\hline \multicolumn{1}{|c|}{ NO NAMA } & NO.BADGE & $\begin{array}{c}\text { NILAIX } \\
(30 \%)\end{array}$ & $\begin{array}{c}\text { NILAIY } \\
(40 \%)\end{array}$ & $\begin{array}{c}\text { NILAI Z } \\
(30 \%)\end{array}$ & $\begin{array}{c}\text { NILAI } \\
\text { AKHIR }\end{array}$ \\
\hline 1 & NURHADI KUSDIANTO & 170126 & 5.00 & 4.95 & 4.65 & 4.88 \\
\hline 2 & DHAMAR SEPTIAN & 170061 & 5.00 & 4.83 & 4.53 & 4.79 \\
\hline 3 & MOH. MARZUQI F & 140041 & 5.00 & 4.95 & 4.35 & 4.79 \\
\hline 4 & IMAM WAHYUDI & 170084 & 5.00 & 4.77 & 4.53 & 4.76 \\
\hline 5 & BAYU SATRIA KUSUMA & 170069 & 4.93 & 4.72 & 4.65 & 4.76 \\
\hline 6 & RIDLO BIAGGI & 170095 & 4.93 & 4.83 & 4.48 & 4.75 \\
\hline 7 & HEMA AYUDHA & 140036 & 4.38 & 4.43 & 4.35 & 4.39 \\
\hline 8 & OKKE BOMARAHANTA & 150094 & 4.08 & 4.52 & 4.13 & 4.27 \\
\hline 9 & M.ADINURA ARRIZKY & 150096 & 3.85 & 4.62 & 3.30 & 3.99 \\
\hline
\end{tabular}

Dari hasil perhitungan metode Profile Matching didapatkan hasil seperti pada tabel 16, menempatkan kandidat dengan nomer badge 170126, Nama Nurhadi Kusdianto pada urutan pertama dengan skor 4.88 .

\subsection{Analisa hasil perhitungan}

Dari hasil yang didapatkan pada pembahasan sebelumnya di poin 4.1 Perhitungan Normal Metode Profile Matching. Akan dilakukan analisa pada hasil perhitungan. Apakah kandidat yang berada pada urutan pertama merupakan kandidat terbaik diantara kandidat yang lain.

Tahap awal dilakukan analisa pada tabel 9 tabel skor kandidat. Kandidat dengan nomor badge 170126 (Nurhadi Kusdianto) yang menempati urutan pertama dibandingkan dengan kandidat dengan nomor badge 170069 (Bayu Satria Kusuma). Berikut tabel 17 perbandingan skor dari kedua kandidat.

Table 17 Perbandingan Skor

\begin{tabular}{|c|c|c|c|c|c|c|c|c|c|c|c|c|c|c|c|c|}
\hline \multirow{2}{*}{ NO } & \multirow{2}{*}{ NAMA } & \multirow{2}{*}{ NO.BADGE } & \multicolumn{5}{|c|}{ ATTITUDE (X) } & \multicolumn{6}{|c|}{ SKILL ( Y ) } & \multicolumn{3}{|c|}{ LOYALITAS ( Z ) } \\
\hline & & & $\mathrm{x} 1$ & $x 2$ & $\mathrm{X} 3$ & $\mathrm{X} 4$ & $\mathrm{x} 5$ & Y1 & Y2 & Y3 & Y4 & Y5 & Y6 & $\mathrm{Z1}$ & $\mathrm{Z2}$ & $\mathrm{Z3}$ \\
\hline 1 & NURHADI KUSDIANTO & 170126 & 4 & 4 & 4 & 4 & 4 & 4 & 4 & 4 & 4 & 4 & 5 & 5 & 5 & 4 \\
\hline 2 & BAYU SATRIA KUSUMA & 170069 & 4 & 4 & 4 & 4 & 5 & 5 & 5 & 4 & 4 & 4 & 5 & 5 & 5 & 4 \\
\hline
\end{tabular}

Dari tabel 17 seharusnya kandidat dengan nomor badge 170069 (Bayu Satria Kusuma) memiliki nilai yang lebih tinggi dari pada kandidat dengan nomor badge 170126 (Nurhadi Kusdianto). Namun hasil akhir perhitungan menetapkan sebaliknya bahkan menempatkan kandidat dengan nomor badge 170069 (Bayu Satria Kusuma) pada urutan kelima dalam pemeringkatan. Dengan hasil yang seperti itu bisa dikatakan bahwa metode profile matching tidak maksimal saat digunakan untuk mencari kandidat terbaik.

Selanjutnya menganalisa tabel 7 Konversi Bobot gap.

Table 18 Analisa Konversi Bobot gap

\begin{tabular}{|c|l|c|}
\hline $\begin{array}{c}\text { Nilai } \\
\text { gap }\end{array}$ & \multicolumn{1}{|c|}{ KETERANGAN } & $\begin{array}{c}\text { BOBOT } \\
\text { NILAI }\end{array}$ \\
\hline $\mathbf{0}$ & TIDAK ADA SELISIH ANTARA NILAI SKOR INDIVIDU DENGAN NILAI PROFIL STANDART & $\mathbf{5}$ \\
\hline $\mathbf{1}$ & NILAI SKOR INDIVIDU LEBIH TINGGI 1 POINT DARI NILAI PROFIL STANDART & $\mathbf{4 . 5}$ \\
\hline-1 & NILAI SKOR INDIVIDU LEBIH RENDAH 1 POINT DARI NILAI PROFIL STANDART & $\mathbf{4}$ \\
\hline 2 & NILAI SKOR INDIVIDU LEBIH TINGGI 2 POINT DARI NILAI PROFIL STANDART & 3.5 \\
\hline-2 & NILAI SKOR INDIVIDU LEBIH RENDAH 2 POINT DARI NILAI PROFIL STANDART & 3 \\
\hline 3 & NILAI SKOR INDIVIDU LEBIH TINGGI 3 POINT DARI NILAI PROFIL STANDART & 2.5 \\
\hline-3 & NILAI SKOR INDIVIDU LEBIH RENDAH 3 POINT DARI NILAI PROFIL STANDART & 2 \\
\hline 4 & NILAI SKOR INDIVIDU LEBIH TINGGI 4 POINT DARI NILAI PROFIL STANDART & 1.5 \\
\hline-4 & NILAI SKOR INDIVIDU LEBIH RENDAH 4 POINT DARI NILAI PROFIL STANDART & 1 \\
\hline
\end{tabular}

Dari tabel 18 bisa disimpulkan bahwa metode Profile Matching merupakan metode yang mencocokkan nilai dengan nilai standart yang ditentukan, nilai yang memiliki bobot tertinggi merupakan nilai yang sesuai. Ketika kandidat mendapatkan nilai 5 atau lebih tinggi dari nilai standart (nilai standart $=4$ ) maka nilai bobot yang 
didapatkan lebih rendah dari pada nilai yang sesuai dengan standart.

\subsection{Perhitungan Modifikasi Metode Profile Matching}

Dari hasil analisa yang dilakuakan pada point 4.2, faktor utama penyebab ketidak sesuaian hasil perhitungan menggunakan metode profile matching dengan nilai asli berada pada nilai konversi bobot. Peneliti mencoba untuk memodifikasi konversi bobot, yang digambarkan pada tabel berikut.

Table 19 Modifikasi Konversi Bobot gap

\begin{tabular}{|c|l|c|}
\hline SELISIH & \multicolumn{1}{|c|}{ KETERANGAN } & BOBOT NILAI \\
\hline 4 & NILAI SKOR INDIVIDU LEBIH TINGGI 4 POINT DARI NILAI PROFIL STANDART & 5 \\
\hline 3 & NILAI SKOR INDIVIDU LEBIH TINGGI 3 POINT DARI NILAI PROFIL STANDART & 4.5 \\
\hline 2 & NILAI SKOR INDIVIDU LEBIH TINGGI 2 POINT DARI NILAI PROFIL STANDART & 4 \\
\hline 1 & NILAI SKOR INDIVIDU LEBIH TINGGI 1 POINT DARI NILAI PROFIL STANDART & 3.5 \\
\hline 0 & TIDAK ADA SELISIH ANTARA NILAI SKOR INDIVIDU DENGAN NILAI PROFIL STANDART & 3 \\
\hline-1 & NILAI SKOR INDIVIDU LEBIH RENDAH 1 POINT DARI NILAI PROFIL STANDART & 2.5 \\
\hline-2 & NILAI SKOR INDIVIDU LEBIH RENDAH 2 POINT DARI NILAI PROFIL STANDART & 2 \\
\hline-3 & NILAI SKOR INDIVIDU LEBIH RENDAH 3 POINT DARI NILAI PROFIL STANDART & 1.5 \\
\hline-4 & NILAI SKOR INDIVIDU LEBIH RENDAH 4 POINT DARI NILAI PROFIL STANDART & 1 \\
\hline
\end{tabular}

Dengan menggunakan konversi bobot sesuai dengan tabel 19, diperoleh nilai konversi gap seperti tabel 20.
Nilai kriteria $\mathrm{X}, \mathrm{Y}$ dan $\mathrm{Z}$ yang diperoleh setelah konversi bobot dimodifikasi seperti tabel 21, tabel 22 dan tabel 23.

Table 20 Konversi gap (Modifikasi)

\begin{tabular}{|c|c|c|c|c|c|c|c|c|c|c|c|c|c|c|c|c|}
\hline \multirow{2}{*}{ NO } & \multirow{2}{*}{ NAMA } & \multirow{2}{*}{ NO.BADGE } & \multicolumn{5}{|c|}{ ATTITUDE (X) } & \multicolumn{6}{|c|}{ SKILL (Y) } & \multicolumn{3}{|c|}{ LOYALITAS ( Z ) } \\
\hline & & & $\mathrm{X} 1$ & $\mathrm{X} 2$ & X3 & $\mathrm{X} 4$ & X5 & Y1 & Y2 & Y3 & Y4 & Y5 & Y6 & $\mathrm{Z1}$ & $\mathrm{Z2}$ & $\mathrm{Z3}$ \\
\hline 1 & HEMA AYUDHA & 140036 & 3 & 2.5 & 3 & 2.5 & 2.5 & 2.5 & 2.5 & 3 & 3 & 2.5 & 3 & 3 & 2.5 & 2.5 \\
\hline 2 & MOH. MARZUQI F & 140041 & 3 & 3 & 3 & 3 & 3 & 3 & 3 & 3 & 3.5 & 3 & 3 & 2.5 & 3 & 2.5 \\
\hline 3 & OKKE BOMARAHANTA & 150094 & 2 & 2.5 & 3 & 2.5 & 2.5 & 2.5 & 3 & 3 & 3.5 & 2.5 & 2.5 & 2 & 3.5 & 3 \\
\hline 4 & M.ADINURA ARRIZKY & 150096 & 2.5 & 2.5 & 2.5 & 2.5 & 2 & 2.5 & 3 & 3 & 3.5 & 2.5 & 3 & 2 & 2 & 2.5 \\
\hline 5 & DHAMAR SEPTIAN & 170061 & 3 & 3 & 3 & 3 & 3 & 3.5 & 3 & 3 & 3 & 3 & 3.5 & 3.5 & 3 & 2.5 \\
\hline 6 & BAYU SATRIA KUSUMA & 170069 & 3 & 3 & 3 & 3 & 3.5 & 3.5 & 3.5 & 3 & 3 & 3 & 3.5 & 3.5 & 3.5 & 3 \\
\hline 7 & IMAM WAHYUDI & 170084 & 3 & 3 & 3 & 3 & 3 & 2.5 & 3 & 3 & 3 & 3 & 3 & 3.5 & 3 & 2.5 \\
\hline 8 & RIDLO BIAGGI & 170095 & 3 & 3 & 3 & 3 & 3.5 & 3.5 & 3 & 3 & 3 & 3 & 3.5 & 3.5 & 2.5 & 3 \\
\hline 9 & NURHADI KUSDIANTO & 170126 & 3 & 3 & 3 & 3 & 3 & 3 & 3 & 3 & 3 & 3 & 3.5 & 3.5 & 3.5 & 3 \\
\hline
\end{tabular}

Table 21 Perhitungan Kriteria X (Modifikasi)

\begin{tabular}{|c|c|c|c|c|c|c|c|c|c|c|}
\hline \multirow{2}{*}{ NO } & \multirow{2}{*}{ NAMA } & \multirow{2}{*}{ NO.BADGE } & \multicolumn{5}{|c|}{ ATTITUDE (X) } & \multirow{2}{*}{$\begin{array}{c}\text { NILAI FAKTOR } \\
\text { UTAMA }\end{array}$} & \multirow{2}{*}{$\begin{array}{l}\text { NILAI FAKTOR } \\
\text { PENDUKUNG }\end{array}$} & \multirow{2}{*}{$\begin{array}{c}\text { NILAI } \\
X\end{array}$} \\
\hline & & & $\mathrm{X} 1$ & $\mathrm{x} 2$ & $x 3$ & $\mathrm{x} 4$ & $\times 5$ & & & \\
\hline 1 & HEMA AYUDHA & 140036 & 3 & 2.5 & 3 & 2.5 & 2.5 & 2.67 & 2.75 & 2.69 \\
\hline 2 & MOH. MARZUQI F & 140041 & 3 & 3 & 3 & 3 & 3 & 3.00 & 3.00 & 3.00 \\
\hline 3 & OKKE BOMARAHANTA & 150094 & 2 & 2.5 & 3 & 2.5 & 2.5 & 2.67 & 2.25 & 2.54 \\
\hline 4 & M.ADINURA ARRIZKY & 150096 & 2.5 & 2.5 & 2.5 & 2.5 & 2 & 2.50 & 2.25 & 2.43 \\
\hline 5 & DHAMAR SEPTIAN & 170061 & 3 & 3 & 3 & 3 & 3 & 3.00 & 3.00 & 3.00 \\
\hline 6 & BAYU SATRIA KUSUMA & 170069 & 3 & 3 & 3 & 3 & 3.5 & 3.00 & 3.25 & 3.08 \\
\hline 7 & IMAM WAHYUDI & 170084 & 3 & 3 & 3 & 3 & 3 & 3.00 & 3.00 & 3.00 \\
\hline 8 & RIDLO BIAGGI & 170095 & 3 & 3 & 3 & 3 & 3.5 & 3.00 & 3.25 & 3.08 \\
\hline 9 & NURHADI KUSDIANTO & 170126 & 3 & 3 & 3 & 3 & 3 & 3.00 & 3.00 & 3.00 \\
\hline
\end{tabular}


Table 22 Perhitungan Kriteria Y (Modifikasi)

\begin{tabular}{|c|c|c|c|c|c|c|c|c|c|c|c|}
\hline \multirow{2}{*}{ NO } & \multirow{2}{*}{ NAMA } & \multirow{2}{*}{ NO.BADGE } & \multicolumn{6}{|c|}{ SKILL ( Y ) } & \multirow{2}{*}{$\begin{array}{l}\text { NILAI FAKTOR } \\
\text { UTAMA }\end{array}$} & \multirow{2}{*}{$\begin{array}{l}\text { NILAI FAKTOR } \\
\text { PENDUKUNG }\end{array}$} & \multirow{2}{*}{$\begin{array}{c}\text { NILAI } \\
Y\end{array}$} \\
\hline & & & $\mathrm{Y} 1$ & Y2 & Y3 & Y4 & Y5 & Y6 & & & \\
\hline 1 & HEMA AYUDHA & 140036 & 2.5 & 2.5 & 3 & 3 & 2.5 & 3 & 2.67 & 2.83 & 2.72 \\
\hline 2 & MOH. MARZUQI F & 140041 & 3 & 3 & 3 & 3.5 & 3 & 3 & 3.00 & 3.17 & 3.05 \\
\hline 3 & OKKE BOMARAHANTA & 150094 & 2.5 & 3 & 3 & 3.5 & 2.5 & 2.5 & 2.83 & 2.83 & 2.83 \\
\hline 4 & M.ADINURA ARRIZKY & 150096 & 2.5 & 3 & 3 & 3.5 & 2.5 & 3 & 2.83 & 3.00 & 2.88 \\
\hline 5 & DHAMAR SEPTIAN & 170061 & 3.5 & 3 & 3 & 3 & 3 & 3.5 & 3.17 & 3.17 & 3.17 \\
\hline 6 & BAYU SATRIA KUSUMA & 170069 & 3.5 & 3.5 & 3 & 3 & 3 & 3.5 & 3.33 & 3.17 & 3.28 \\
\hline 7 & IMAM WAHYUDI & 170084 & 2.5 & 3 & 3 & 3 & 3 & 3 & 2.83 & 3.00 & 2.88 \\
\hline 8 & RIDLO BIAGGI & 170095 & 3.5 & 3 & 3 & 3 & 3 & 3.5 & 3.17 & 3.17 & 3.17 \\
\hline 9 & NURHADI KUSDIANTO & 170126 & 3 & 3 & 3 & 3 & 3 & 3.5 & 3.00 & 3.17 & 3.05 \\
\hline
\end{tabular}

Table 23 Perhitungan Kriteria Z (Modifikasi)

\begin{tabular}{|c|c|c|c|c|c|c|c|c|}
\hline \multirow{2}{*}{ NO } & \multirow{2}{*}{ NAMA } & \multirow{2}{*}{ NO.BADGE } & \multicolumn{3}{|c|}{ LOYALITAS ( Z ) } & \multirow{2}{*}{$\begin{array}{c}\text { NILAI FAKTOR } \\
\text { UTAMA }\end{array}$} & \multirow{2}{*}{$\begin{array}{l}\text { NILAI FAKTOR } \\
\text { PENDUKUNG }\end{array}$} & \multirow{2}{*}{ NILAI Z } \\
\hline & & & $\mathrm{Z1}$ & $\mathrm{Z2}$ & $\mathrm{Z3}$ & & & \\
\hline 1 & BAYU SATRIA KUSUMA & 170069 & 3 & 2.5 & 2.5 & 2.75 & 2.50 & 2.68 \\
\hline 2 & NURHADI KUSDIANTO & 170126 & 2.5 & 3 & 2.5 & 2.75 & 2.50 & 2.68 \\
\hline 3 & RIDLO BIAGGI & 170095 & 2 & 3.5 & 3 & 2.75 & 3.00 & 2.83 \\
\hline 4 & DHAMAR SEPTIAN & 170061 & 2 & 2 & 2.5 & 2.00 & 2.50 & 2.15 \\
\hline 5 & IMAM WAHYUDI & 170084 & 3.5 & 3 & 2.5 & 3.25 & 2.50 & 3.03 \\
\hline 6 & MOH. MARZUQI F & 140041 & 3.5 & 3.5 & 3 & 3.50 & 3.00 & 3.35 \\
\hline 7 & OKKE BOMARAHANTA & 150094 & 3.5 & 3 & 2.5 & 3.25 & 2.50 & 3.03 \\
\hline 8 & HEMA AYUDHA & 140036 & 3.5 & 2.5 & 3 & 3.00 & 3.00 & 3.00 \\
\hline 9 & M.ADINURA ARRIZKY & 150096 & 3.5 & 3.5 & 3 & 3.50 & 3.00 & 3.35 \\
\hline
\end{tabular}

Dari hasil perhitungan kriteria $\mathrm{X}, \mathrm{Y}$ dan $\mathrm{Z}$ maka didapatkan nilai akhir seperti pada tabel 24. Dan hasil nilai akhir yang didapatkan dengan melakukan perhitungan menggunakan modifikasi konversi bobot dapat dirangking seperti tabel 25.

Table 24 Perhitungan Nilai Akhir (Modifikasi)

\begin{tabular}{|c|l|c|c|c|c|c|}
\hline NO & \multicolumn{1}{|c|}{ NAMA } & NO.BADGE & $\begin{array}{c}\text { NILAI X } \\
(30 \%)\end{array}$ & $\begin{array}{c}\text { NILAI Y } \\
(40 \%)\end{array}$ & $\begin{array}{c}\text { NILAI Z } \\
(30 \%)\end{array}$ & $\begin{array}{c}\text { NILAI } \\
\text { AKHIR }\end{array}$ \\
\hline 1 & HEMA AYUDHA & 140036 & 2.69 & 2.72 & 2.68 & 2.70 \\
\hline 2 & MOH. MARZUQI F & 140041 & 3.00 & 3.05 & 2.68 & 2.92 \\
\hline 3 & OKKE BOMARAHANTA & 150094 & 2.54 & 2.83 & 2.83 & 2.74 \\
\hline 4 & M.ADINURA ARRIZKY & 150096 & 2.43 & 2.88 & 2.15 & 2.53 \\
\hline 5 & DHAMAR SEPTIAN & 170061 & 3.00 & 3.17 & 3.03 & 3.07 \\
\hline 6 & BAYU SATRIA KUSUMA & 170069 & 3.08 & 3.28 & 3.35 & 3.24 \\
\hline 7 & IMAM WAHYUDI & 170084 & 3.00 & 2.88 & 3.03 & 2.96 \\
\hline 8 & RIDLO BIAGGI & 170095 & 3.08 & 3.17 & 3.00 & 3.09 \\
\hline 9 & NURHADI KUSDIANTO & 170126 & 3.00 & 3.05 & 3.35 & 3.13 \\
\hline
\end{tabular}

Table 25 Hasil Ranking (Modifikasi)

\begin{tabular}{|c|l|c|c|c|c|c|}
\hline NO & \multicolumn{1}{|c|}{ NAMA } & NO.BADGE & $\begin{array}{c}\text { NILAI X } \\
(30 \%)\end{array}$ & $\begin{array}{c}\text { NILAIY } \\
(40 \%)\end{array}$ & $\begin{array}{c}\text { NILAIZ } \\
(30 \%)\end{array}$ & $\begin{array}{c}\text { NILAI } \\
\text { AKHIR }\end{array}$ \\
\hline 1 & BAYU SATRIA KUSUMA & 170069 & 3.08 & 3.28 & 3.35 & 3.24 \\
\hline 2 & NURHADI KUSDIANTO & 170126 & 3.00 & 3.05 & 3.35 & 3.13 \\
\hline 3 & RIDLO BIAGGI & 170095 & 3.08 & 3.17 & 3.00 & 3.09 \\
\hline 4 & DHAMAR SEPTIAN & 170061 & 3.00 & 3.17 & 3.03 & 3.07 \\
\hline 5 & IMAM WAHYUDI & 170084 & 3.00 & 2.88 & 3.03 & 2.96 \\
\hline 6 & MOH. MARZUQI F & 140041 & 3.00 & 3.05 & 2.68 & 2.92 \\
\hline 7 & OKKE BOMARAHANTA & 150094 & 2.54 & 2.83 & 2.83 & 2.74 \\
\hline 8 & HEMA AYUDHA & 140036 & 2.69 & 2.72 & 2.68 & 2.70 \\
\hline 9 & M.ADINURA ARRIZKY & 150096 & 2.43 & 2.88 & 2.15 & 2.53 \\
\hline
\end{tabular}


Dari hasil pemeringkatan pada tabel 25 mengindikasikan bahwasanya perhitungan metode Profile Matching

\section{Kesimpulan}

Dari hasil analisis perhitungan metode Profile Matching dapat ditarik kesimpulkan sebagai berikut:

1) Metode Profile Matching kurang sesuai untuk digunakan dalam kasus menentukan kandidat terbaik.

2) Pembobotan gap merupakan faktor utama yang mempengaruhi hasil perhitungan. Ketika menggunakan konversi nilai gap seperti pada tabel 7 , hasil perhitungan metode tidak memberikan hasil yang maksimal.

3) Untuk memaksimalkan perhitungan metode Profile Matching dalam kasus menentukan kandidat terbaik dapat dilakukan dengan 2 solusi. Yang pertama adalah dengan menggunakan nilai standart yang paling tinggi (sesuai dengan penelitian umam cs) dan yang kedua adalah menggunakan konversi nilai gap seperti pada tabel 19 .

\section{Daftar Pustaka}

Astriratma, R., Wardoyo, R., \& Musdholifah, A. (2017). SPK Rekomendasi Pemilihan Kandidat Pejabat Struktural Menggunakan Metode Profile Matching. IJCCS, 77-88.

Giansister. (2017, Oktober 16). Pengertian Sistem Pengambil Keputusan (SPK) Beserta Contohnya. Retrieved from giansister.wordpress.com: https://giansister.wordpress.com/2017/10/16/p engertian-sistem-pengambil-keputusan-spkbeserta-contohnya/

Haryani, \& Fitriani, D. (2019). Sistem Pendukung Keputusan Penentuan Karyawan Terbaik Pada Collection PT.PANIN BANK Menggunakan Metode Profile Matching. Jurnal Mantik Penusa, 1-8.

Kementerian Pendidikan dan Kebudayaan Republik Indonesia. (2016, Oktober 28). Retrieved from kbbi.kemdikbud.go.id: https://kbbi.kemdikbud.go.id/entri/kandidat

Purwanto, H. (2017). Penerapan Metode Profile Matching Dalam Sistem Pendukung Keputusan Penilaian Kinerja Karyawan Pada PT. Hyundai Mobil Indonesia Cabang Kalimalang. Jurnal Techno Nusa Mandiri, 15-20.

Sudrajat, B. (2018, Oktober 1). Pemilihan Pegawai Berprestasi dengan Menggunakan Metode Profile Matching. Sinkron Jurnal \& Penelitian Teknik Informatika, Vol. 3(1), 202-210.

Susilo, A. A. (2017). Penerapan Metode Profile Matching pada Sistem Pendukung Keputusan Pemilihan Ketua Program Studi (STUDI Kasus: Program Studi Teknik Informatika STMIK Musi Rawas). JUITA, 87-93.

Umam, M. C., Arifianto, D., \& Cahyanto, T. A. (2016). Sistem Pendukung Keputusan Pemilihan Karyawan Berprestasi di Universitas Muhammadiyah Jember Dengan Menggunakan Metode Profile Matching. Universitas Muhammadiyah Jember, Jurusan Teknik Informatika Fakultas Teknik. Jember: OSF Home. doi:10.31227/osf.io/3anmf 